\title{
O linchamento ao redor do mundo: ocorrências no Brasil e no mundo a partir do ano 2000
}

\author{
The linching around the world: occurrences in Brazil and \\ in the world from 2000 on \\ El linchamiento alrededor del mundo: acontecimientos en Brasil y en \\ todo el mundo desde el año 2000
}

Mary Cristina Neves Mansoldo ${ }^{1}$

\section{Resumo}

MANSOLDO, Mary Cristina Neves. O linchamento ao redor do mundo: ocorrências no Brasil e no mundo a partir do ano 2000. Rev. C\&Trópico, vol. 43, n. 2, p. 83-109, 2019. DOI: https://doi. org/10.33148/Cetropicov43n2(2019)art.4

Neste artigo de investigação e reflexão crítica, resultado de pesquisa de doutoramento em Criminologia que ainda está em andamento, analisamos a conduta de linchamento no Brasil e realizamos um estudo comparado por amostragem conveniente e não exaustiva, pesquisando sobre ocorrências de linchamento ao redor do mundo a partir do ano 2000. O linchamento foi compreendido como a conduta de linchar outro(s) da mesma espécie em local público e com a participação de vários linchadores. Com a investigação de amostragem, objetivamos um estudo comparado entre o Brasil e outros países. Concluímos pela existência de ocorrências em muitos países, porém, com diferentes motivações. Ainda chegamos à conclusão que, na maioria dos países que constam como mais pacíficos no relatório Global Peace Index de 2018, não há notícias de linchamentos. As metodologias utilizadas foram de revisão bibliográfica e levantamentos de casos noticiados por mídias jornalísticas. Justificam-se o estudo e a análise por se tratarem de uma conduta que caminha na "contramão"dos direitos humanos, do Estado de Direito e democrático. Objetivamos, por fim, contribuir com pesquisas científicas e acadêmicas no âmbito da Ciência da Criminologia.

Palavras-chave: Linchamento. justiça com as próprias mãos. Criminologia.

Doutoranda em Criminologia pela Universidade do Porto (Portugal). E-mail: marymansoldo@hotmail.com Orcid: https://orcid.org/0000-0001-9000-9786 


\section{Abstract}

MANSOLDO, Mary Cristina Neves. The linching around the world: occurrences in Brazil and in the world from 2000 on. Rev. C\&Trópico, vol. 43, n. 2, p. 83-109, 2019. https://doi.org/10.33148/ Cetropicov43n2(2019)art.4

In this article of research and critical reflection, a result of doctoral research in Criminology that is still in progress, we analyzed the lynching behavior in Brazil and carried out a comparative study by convenient and non-exhaustive sampling, investigating on lynching occurrences around the world from the year $2000 \mathrm{on}$. The lynching was understood as the conduct of lynching other (s) of the same species in a public place and with the participation of several lynchers. With the sampling investigation, we aimed a comparative study between Brazil and other countries. We conclude by the existence of occurrences in many countries, but with different motivations. As we also concluded that in most of the countries listed as more peaceful in the 2018 Global Peace Index report, we found no news of lynching. The methodologies used were bibliographic review and case studies reported by journalistic media. It justifies the study and analysis because it is a conduct that walks in the "counter" of human rights, the rule of law and democratic. We aim to contribute scientific and academic research in the field of Criminology Science.

Keywords: Lynching. justice with your own hands. Criminology.

\section{Resumen}

MANSOLDO, Mary Cristina Neves. El linchamiento alrededor del mundo: acontecimientos en Brasil y en todo el mundo desde el año 2000. Rev. CઐTrópico, vol. 43, n. 2, p. 83-109, 2019. https://doi. org/10.33148/Cetropicov43n2(2019)art.4

En este artículo de investigación y reflexión crítica, resultado de investigación de doctorado en Criminología que aún está en marcha, analizamos la conducta de linchamiento en Brasil y realizamos un estudio comparado por muestreo conveniente y no exhaustivo, investigando sobre ocurrencias de linchamiento alrededor del mundo a partir del año 2000. El linchamiento fue comprendido como la conducción de linchar otro(s) de la misma especie en local público y con la participación de varios linchadores. Con la investigación de muestreo, objetivamos un estudio comparado entre Brasil y otros países. Aún más, Concluimos por la existencia de sucesos en muchos países, pero con diferentes motivaciones. Como, también, concluimos que en la mayoría de los países que figuran como más pacíficos en el informe Global Peace Index de 2018, no encontramos noticias de linchamientos. Las metodologías utilizadas fueron de revisión bibliográfica y levantamientos de casos noticiados por medios periodísticos. Se justifica el estudio y análisis por tratarse de una conducta que camina en la "contra" de derechos humanos, del Estado de Derecho y democrático. Objetivamos contribuir con investigaciones científicas y académicas en el ámbito de la Ciencia de la Criminología.

Palabras clave: Linchamiento. justicia con sus propias manos. Criminología. 


\section{Introdução}

Neste artigo de investigação e reflexão crítica, resultado de pesquisa de doutoramento em Criminologia, ainda em andamento, analisamos a conduta de linchamento no Brasil e realizamos um estudo comparado por amostragem conveniente e não exaustiva, pesquisando sobre ocorrências de linchamento ao redor do mundo a partir do ano 2000. O linchamento foi compreendido como a conduta de linchar outro(s) da mesma espécie em local público e com a participação de vários linchadores, conforme será analisado a seguir.

De acordo com a pesquisa realizada por Rosanne D’Agostino et al. (2014), no primeiro semestre de 2014, ocorreram 50 casos de linchamentos no Brasil, ou seja, em média oito linchamentos por mês. Em 30 casos, desses 50 linchamentos, o crime supostamente cometido pelo linchado era de furto ou roubo (60\%); em dez casos, o crime suposto era de estupro; em quatro, agressão; em três, assassinato; em dois, crime de trânsito; e em um, o suposto crime envolvia bruxaria (D’AGOSTINO et al, 2014). Este foi o único linchamento de mulher. Configurase, pois, da seguinte forma:

Gráfico 1: Linchamentos no primeiro semestre de 2014

\section{LINCHAMENTOS - 1ㅇ SEM. DE 2014}

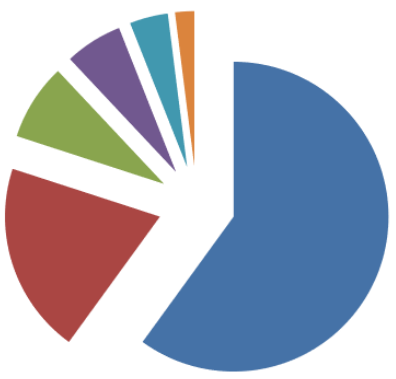

ROUBO E FURTO

ESTUPRO

AGRESSÃO

ASSASSINATO

TRÂNSITO

BRUXARIA

Fonte: Elaboração própria a partir de Dados de pesquisa realizada por D’Agostino et al, 2014.

Os estudos sobre linchamentos, realizados no Brasil, fundamentam-se basicamente por meio de materiais jornalísticos, por depoimentos daqueles que presenciaram o momento da ação e/ou por moradores do local em que a conduta ocorreu como, por exemplo, estudos realizados por Benevides (1982); Rios (1988); Menandro (1991); Martins (1996); Sinhoretto (2001); Singer (2003); Oliveira (2010); Natal (2012), entre outros. Ainda são poucos os estudos de caso, o que demonstra fonte escassa de informações no que diz respeito aos âmbitos judiciais e processuais penais. 
Ariadne Lima Natal (2012) pesquisou sobre os trinta anos de linchamentos na Região Metropolitana de São Paulo (de 1980 a 2009), mas relata a dificuldade no levantamento de dados oficiais, constatando, dessa forma, que a principal fonte de dados é a imprensa. Conforme a pesquisadora, um dos fatores que dificulta a coleta de dados oficiais sobre o linchamento é a impunidade. Isso ocorre por dois motivos relevantes: primeiro por ser uma conduta ilícita cometida por várias pessoas, dificultando as identificações dos agentes, bem como, as responsabilidades individuais de cada envolvido; segundo, por não haver testemunhas suficientes, já que algumas pessoas consideram como uma reação social legítima, por acreditarem que os agredidos são "merecedores" das agressões, ocorrendo, assim, a predominância da lei do silêncio.

Paulo Rogério Meira Menandro e Lídio de Souza, ambos doutores em Psicologia pela Universidade de São Paulo, publicaram, em 1991, o livro Linchamentos no Brasil: a justiça que não tarda, mas falha - uma análise a partir de dados obtidos através da imprensa escrita. Segundo os pesquisadores, no Brasil, no período de 1853 a 1990, embora não existam dados oficiais, ocorreram 533 episódios de linchamentos, aos quais foram vitimizadas 753 pessoas.

Souza (1999) publicou o artigo "Judiciário e exclusão: O linchamento como mecanismo de reafirmação de poder”, nesse artigo científico é apresentado um estudo de caso ocorrido em uma cidade do interior brasileiro, na qual foram executados três suspeitos de envolvimento em um homicídio na localidade. Com isso, o autor objetivou identificar as implicações das instituições policiais e judiciárias em um linchamento.

José de Souza Martins, escritor, sociólogo, Professor Titular aposentado do Departamento de Sociologia e Professor Emérito (2008) da Faculdade de Filosofia, Letras e Ciências Humanas da Universidade de São Paulo (FFLCH-USP), realizou um trabalho científico sobre o linchamento que foi apresentado no Painel Extra-legal violence in Brazil: Popular Justice, Vigilantism and Lynching, $3^{\text {a }}$ Conferência do Brazilian Studies Association, Cambridge (Reino Unido), em setembro de 1996. Além do mais, entre várias obras literárias, publicou também o livro 'Linchamentos - A justiça popular no Brasil" no ano de 2015. Nessa obra, o autor visa apresentar os resultados de um amplo mapeamento de notícias de jornais brasileiros sobre o fenômeno do linchamento no Brasil. Os dados coletados cobrem um período de quase sessenta anos que, conforme Martins, revelam o Brasil como um dos países que mais lincha no mundo. Conforme José de Souza Martins (2015), no Brasil, acontece, pelo menos, um linchamento ou tentativa de linchamento por dia. Tratando-se, portanto, de um fenômeno recorrente no Brasil.

É salutar, no entanto, uma análise sobre a ocorrência em outros países, para tanto, realizamos uma investigação por amostragem não exaustiva a partir do ano 2000. Como, também, verificamos o relatório Global Peace Index de 2018 e realizamos uma comparação entre os países mais pacíficos e os casos de linchamento.

Dessa forma, pela relevância do tema, neste artigo serão apresentados conceitos e exemplos de casos de linchamentos ocorridos no Brasil e amostragem de ocorrências em outros países, objetivando uma comparação do fenômeno ao redor do mundo. 


\section{A conduta de linchamento no Brasil}

Em uma conceituação básica e clássica, o linchamento ${ }^{2}{ }^{3}$ ou linchagem ocorre quando uma multidão (moradores do local, vizinhos, conhecidos, transeuntes da rua, etc.), objetivando punir um suposto criminoso ou delinquente, mata-o ou o lesiona-o. Trata-se de uma violência exacerbada em espetáculo público. Normalmente, os linchamentos ocorrem pela participação ativa de um grupo efêmero e sem organização prévia. Portanto, em primeiro momento, podemos observar que a conduta do linchamento ocorre por uma explosão de sentimentos e emoções que levam a ações irracionais (BENEVIDES, 1982; RIOS, 1988; MENANDRO, 1991; MARTINS, 1996; SINHORETTO, 2001; ADORNO \& PASINATO, 2007; SINGER, 2003; OLIVEIRA, 2010; NATAL, 2012).

Conforme Martins (1996), os linchamentos ocorrem por julgamentos súbitos de acusadores anônimos, repletos de sentimentos conflitantes, como o ódio e o medo, sem neutralidade que, em um devido processo penal, é representado pela figura de um juiz.

Oliveira (2010, p. 3) identifica o clássico linchamento como: "Espancamento ou morte de indivíduo(s) acusado(s) de ter (em) cometido atitude criminosa ou moralmente reprovável, por moradores ou transeuntes de uma localidade”. A pesquisadora esclarece que tais casos de linchamento ocorrem antes que a polícia chegue ao local e o grupo de linchadores, inicialmente, sente-se incomodado, ferido moralmente pelo crime que, supostamente, foi cometido por aquele que será linchado, assim, decidindo pela melhor solução: a agressão.

Há, porém, casos em que são cometidos com planejamento, por exemplo, no caso de comunidades que se unem para "pegar" um determinado criminoso, ou seja, uma união planejada de justiceiros. Ou casos em que há votações entre os integrantes da comunidade para decidirem se vão entregar o criminoso à polícia ou se vão linchar o criminoso, como no depoimento abaixo que relata uma ocorrência em que participavam cerca de 150 moradores:

Eu assisti a votação, mas não participei do linchamento. Vi tudo e acho que as pessoas estavam certas em linchar. Aliás, foram as donas de casa as que mais defenderam sua morte. [...] Alguém gritou que era a hora de votar: vamos entregar a polícia? Nin-

\footnotetext{
2 É salutar observarmos que, no que diz respeito à origem da palavra linchamento, a terminologia, em 1837, nos Estados Unidos, influenciada pela história de Charles Lynch, fazendeiro da Virgínia, que era um coronel da Revolução Americana. O coronel liderou uma organização privada que perseguia os negros e os índios, fato que originou a lei de Lynch. Como, também, originou a organização Ku Klux Klan (OLIVEIRA, 2010).

3 Como reação às medidas favoráveis à integração dos negros na sociedade sulista, surgiu em 1866, a Ku Klux Klan, no estado do Tennessee. Um ano depois a organização já havia crescido e atingia outras regiões. A maior parte dos líderes eram ex-soldados do exército sulista que tinham lutado contra a abolição na Guerra de Secessão. Já adoptando, desde então, as vestes pelas quais ficariam mundialmente conhecidos, com seus rostos e corpos cobertos por lençóis brancos até ao tornozelo. Iniciava-se uma história de violências e atrocidades sem igual nos registros norte-americanos. Perseguições aos negros e, posteriormente, a ampliação de seu raio de acção, com acções radicais e covardes contra outras minorias como os judeus, católicos, socialistas, comunistas, simpatizantes dos direitos civis e hispânicos (MACHADO, 2018, p. 1).
} 
guém levantou a mão, vamos linchar? Todos concordaram. [...] Se eu tivesse que votar, votava outra vez pela morte dele, agora eu me sinto segura...Aqui a polícia nunca aparece, só vem quando o corpo já está frio (NATAL, 2012, p. 142-143).

Sinhoretto (2001), em sua pesquisa de dissertação, conceitua o linchamento como execução sumária de pessoas consideradas criminosas, podendo ocorrer por ações espontâneas ou planejadas, apesar de preferir identificar tais condutas como originárias de uma razão que concorre com a racionalidade de uma justiça oficial.

Adorno e Pasinato (2007) acrescentam que o linchamento pode ter um ou mais indivíduos como vítimas. Os linchadores consideram esses indivíduos responsáveis por crimes ou ameaças que perturbam a vida da comunidade. O objetivo dos linchadores é observável por indícios como: "gritos de intenção, posse de instrumentos letais (instrumentos contundentes, às vezes armas brancas e até mesmo armas de fogo), depredações de construções e edifícios, públicos e privados" (ADORNO; PASINATO, 2007, p.138).

Há, ainda, linchamentos de "justiça popular", em situações que ocorrem o assassinato por questões de discriminação, preconceito ou com o objetivo de reprimir adversários e opostos. De qualquer forma, eles são cometidos por cidadãos que visam supostas defesas de justiça e paz social ou que, simplesmente, envolvem-se emocional, mental ou psicologicamente com o momento de agressão. Um exemplo desse tipo de linchamento ocorreu no Brasil, em 2014, e foi amplamente noticiado em matérias jornalísticas. O caso envolveu a dona de casa Fabiane Maria de Jesus, morta aos 33 anos por espancamento por moradores de Guarujá no Estado de São Paulo, onde morava. Fabiane foi acusada de praticar magia negra com crianças após uma notícia falsa espalhada pelas redes sociais. Ela foi amarrada e agredida por dezenas de pessoas, mas somente cinco foram identificadas e condenadas pelo assassinato (GLOBO, 2017).

Os linchamentos, também, podem representar culturas ou crenças de um povo ou região, ocorrendo de maneira ritualística e com a participação de todos os integrantes da comunidade.

No momento do linchamento, há aqueles que lideram as agressões, aqueles que auxiliam e, ainda, incentivam com palavras e gritos e os que apenas observam calados e omissos a aniquilação da vítima, sejam mulheres, homens, idosos, jovens ou crianças. Sobre isso esclarece Oliveira (2010, p. 6): "Aqueles que se autodenominam como "pessoas de bem" são aquelas que fazem parte da cena do linchamento e interpretam um papel no roteiro, seja o de defensor, espectador, provocador ou linchador”. É perceptível, contudo, uma espécie de simbiose entre os que participam do momento. Há uma união de ideias e sentimentos de vingança, execução sumária e justiça social. Sobre um linchamento ocorrido em Parelheiros, zona Sul de São Paulo. Natal (2012), em sua dissertação, relata o depoimento de uma testemunha que identifica a referida simbiose ou união de propósitos: "Eles gritavam muito, durante uns 40 minutos eles bateram no coitado que nem gritava mais. Diziam com raiva que era para bater mais, para matar logo" (2012, p. 128, destaque nosso). 
Há certa estrutura (ou ritual) na conduta do linchamento clássico, ou seja, naquele que ocorre na rua e é cometido por moradores e transeuntes do local, o que nos faz observar um ritualismo repetitivo. Oliveira (2010). descreve a ordem dos acontecimentos observada em análises feitas em vários vídeos publicados sobre linchamentos ocorridos no Brasil:

1. A população se aglomera em torno do acusado e é iniciada a agressão verbal. Um indivíduo, que é percebido como o instigador inicia a propagação de palavras de ordem, que tendem a acusar e humilhar o suposto criminoso, com xingamentos;

2. O linchado tenta se defender, ao vociferar algumas palavras que tentam tirar a sua culpa, porém, não é ouvido pela população;

3. O acusado já foi jogado ao chão e está parcialmente imobilizado. Continuam os xingamentos da cena 1, que dura durante todo o linchamento, e alguém dá o primeiro pontapé no acusado, dado à distância;

4. Um após o outro as pessoas iniciam a seqüência de agressões, que após os pontapés, são seguidos por socos no corpo (geralmente costelas e costas) e tapas na face;

5. Quanto mais demora a chegada da polícia, mas vigorosas vão ficando as agressões. Elas começam a se intensificar, e os linchadores começam a utilizar utensílios, principalmente pedaços de madeira e pedras;

6. A população ao redor aumenta, a maioria não participa do linchamento, apenas grita durante o evento, sejam palavras ofensivas contra o acusado, sejam comemorações após cada agressão;

7. Marcas de sangue começam a ser percebidas e é geralmente neste momento que chega ou intervém a polícia (que em alguns poucos casos está presente, mas não toma qualquer atitude), que percebendo a intensidade dos ferimentos, resgata o linchado e o leva para a delegacia - é aqui que termina a maioria dos vídeos; 8. Quando a polícia não se faz presente, as agressões continuam e o linchado começa a apresentar sinais de desfalecimento;

9. A população intensifica as agressões, principalmente as pauladas; 10. O linchado morre;

11. A população comemora, e mesmo percebendo a morte, continua a dar chutes espaçados no corpo (OLIVEIRA, 2010, p. 10-11).

Rios (1988, p. 218-219) relata sobre o linchamento: "é um crime de massa, seu autor não tem rosto. Impossível individuá-lo. Sua regra é o anonimato. [...] na boca das testemunhas, a mesma frase: 'Não reconheci ninguém, não conheço ninguém, não me lembro de ninguém.” O pesquisador enfatiza concluindo: "Daí a dificuldade de 
apurar esse delito infame. $\mathrm{O}$ indivíduo desaparece na multidão ululante, monstro de cem cabeças; todas iguais no ódio e na vindita, todas indistintas”.

No que diz respeito ao merecimento dos linchados (ainda que, em muitos casos, fique comprovado que o linchado não tenha qualquer envolvimento com o ato que lhe fora imputado), Sinhoretto (2001, p. 170, grifo nosso) relata o caso ocorrido no Jd. Míriam, Zona Sul de São Paulo, em 18 de maio de 1982. Pessoas que presenciaram o ocorrido relataram que a revolta era tanta que as pessoas gritavam para os policiais: "ele merecia morrer. Aos gritos de "mata o Judas", "assassino", teriam partido para cima da viatura, arrancado Messias de dentro dela e o espancado muito; [...]". Nesse caso, os policiais tentaram salvar a vida da vítima, mas foi em vão, ele morreu no hospital.

Natal (2012) enfatiza que, em um linchamento, principalmente quando o linchado supostamente cometeu um crime considerado grave, é como se este perdesse o direito de seu próprio corpo. Em outras palavras, há a necessidade de desincorporar e desumanizar o linchado, como expõe Martins: "Essas práticas indicam que estamos em face de rituais de exclusão ou desincorporação e dessocialização de pessoas que, pelo crime cometido, revelaram-se incompatíveis com o gênero humano, como se tivessem exposto, por meio dele, que nelas prevalece a condição de não-humanas" (NATAL, 2012, p. 131). Ele conclui que "as mutilações e queimas de corpos praticadas nesses casos são desfigurações que reduzem o corpo da vítima a um corpo destituído de características propriamente humanas. São, portanto, rituais de desumanização daqueles cuja conduta é socialmente imprópria" (MARTINS, 1996, p. 20).

$\mathrm{O}$ pesquisador salienta que, para os linchadores, não basta retirar da vida o corpo físico daquele que cometeu um crime e foi linchado. É necessário, também, retirá-lo como pessoa da sociedade, apagando sua memória como pessoa, havendo, portanto, simbolicamente, uma dupla morte. Exemplificando com o linchamento de cadáveres, ou seja, "Para que matar o morto?" (MARTINS, 1996, p. 21).

Outros exemplos podem ser apontados sobre esta necessidade de "dupla morte", como nos casos em que o linchamento é executado com lento ritual de sacrifício e o corpo da vítima é amarrado em um poste para sua exposição que, na realidade, visa à humilhação e a exteriorização do poder social e, supostamente, humano. Em suma, a sociedade se apossa duplamente do indivíduo criminoso. Um exemplo pode ser apresentado em um linchamento ocorrido em São Luís no Maranhão em 7 de julho de 2015: “[...] Silva foi despido e amarrado pelas mãos, pés e tronco a um poste na rua, local em que foi atacado pela população com chutes, socos, pedradas e garrafadas. [...] uma multidão se reuniu para observar o homem morto e amarrado ao poste" (JORNAL ESTADO DE S.PAULO, 2015), como, também, em outros casos, nos quais o modo operante é o mesmo, i.e., amarrar a vítima em postes, grades, etc.

No Brasil, os linchamentos ocorrem, com mais frequência, em regiões mais carentes, porém, há casos de linchamentos em regiões mais elitizadas, como no caso ocorrido no bairro de Copacabana, Rio de Janeiro, em um restaurante, onde houve uma denúncia de comida vencida no refrigerador do estabelecimento (OLIVEIRA, 2010). 
Desse modo, podemos supor que a conduta do linchamento é uma forma arcaica de punição que ocorre até os dias atuais, mas, essa conclusão não seria suficiente para entendermos a gravidade de tais comportamentos humanos. E, muito menos, tal conclusão possibilitaria aos poderes públicos a criação de medidas que, realmente, viessem a impedir a criminalidade em análise. Além disso, seria insuficiente pensarmos que o linchamento é uma violência-resposta à violência urbana ou um retrato da incivilização. Isso tudo pelo fato de estarmos diante de uma condição humana muita mais complexa. O linchamento, que é fortalecido pela união de muitos, representa uma exteriorização de poder que o indivíduo sozinho não conseguiria vivenciar. Martins (1996) ressalta que, em se tratando de aglomerações e multidões, o indivíduo se transforma, conseguindo ser ele mesmo e, ao mesmo tempo, ser todos os indivíduos presentes. Em outras palavras, sozinho ele não faria todas aquelas coisas, ele não lincharia. Há, portanto, uma dupla personalidade que se manifesta (e se materializa) no participante, “[...] nela, o homem da vigília, da lei e da razão, cede lugar ao linchador, que faz justiça pelas próprias mãos, contra todos os princípios da luminosidade transparente e todos os princípios da razão" (MARTINS, 1996, p. 23-24).

Não há, no ordenamento jurídico brasileiro, um tipo penal específico de linchamento. $\mathrm{O}$ fato por si só constitui o crime de fazer justiça pelas próprias mãos, denominado exercício arbitrário das próprias razões (CÓDIGO PENAL BRASILEIRO, 1940, art. 345), sem prejuízo da violência cometida contra a vítima, o que significa que os agentes delituosos respondem pelo resultado de suas condutas, como pelo tipo penal de homicídio (art. 121 do CPB) ou de lesão corporal (art. 129 do CPB). Também podem responder pelo tipo penal de tortura infringindo a Lei 9455/97, art. $1^{\circ}$ (LEI DE TORTURA, 1997). O fato de não existir um tipo penal específico dificulta o levantamento da criminalidade de linchamento nas fontes oficiais, a conduta é considerada, por exemplo, como homicídio doloso, não sendo diferenciado o homicídio comum do linchamento.

Neste tópico, citamos alguns exemplos de casos de linchamentos ocorridos no Brasil, objetivando identificar e delimitar a conduta agressiva em análise. Observamos, no entanto, observamos que o linchamento faz parte de muitas culturas e realidades sociais ao redor do mundo. Assim, objetivando um estudo comparado, apresentaremos no próximo tópico amostragem sobre acontecimentos de linchamento ao redor do mundo.

\section{O linchamento ao redor do mundo: estudo comparado por exemplificação}

Antes de apresentarmos a amostragem sobre a conduta de linchamento ao redor do mundo, serão feitos alguns apontamentos sobre o Global Peace Index, pois, apesar dos dados do relatório não se referirem, especificamente, sobre a conduta de linchamento, objeto de estudo de nosso artigo, permite-nos saber quais foram os países considerados mais e menos pacíficos do mundo.

No relatório Global Peace Index (Índice Global da Paz - 12a edição), publicado no mês de junho de 2018, pelo The Institute for Economics \& Peace (IEP), foram 
considerados como os vinte países (no total de 163 países - 99,7\% da população mundial) mais pacíficos do mundo, são eles (posições: 1 a 20):

- Islândia, Nova Zelândia, Áustria, Portugal, Dinamarca, Canadá, República Checa, Singapura, Japão, Irlanda, Eslovênia, Suíça, Austrália, Suécia, Finlândia, Noruega, Alemanha, Hungria, Butão e Maurícia. (IEP, 2018).

$\mathrm{Na}$ outra ponta do ranking, os vinte países que possuem menor índice de paz são (posições: 144 a 163):

- Mali, Colômbia, Israel, Líbano, Nigéria, Turquia, Coréia do Norte, Paquistão, Ucrânia, Sudão, Rússia, Rep. Centro-Africana, Dem. Rep. Congo, Líbia, Iêmen, Somália, Iraque, Sudão do Sul, Afeganistão e Síria.

Observa-se que a lista dos países mais pacíficos, com exceção de Nova Zelândia (Oceania), Canadá (América do Norte), Singapura (Ásia), Japão (Ásia), Butão (Ásia) e Maurícia (África), os outros 14 países encontram-se na Europa. Por sua vez, a lista dos países menos pacíficos, oito deles estão na África, seis no Oriente Médio, três na Ásia, um na América do Sul, um na Europa e um na Eurásia (Europa e Ásia - Rússia).

No geral, a Europa, apesar de haver tido uma queda registrada devido à instabilidade política, impacto do terrorismo e ocorrências de criminalidade, manteve a posição de região mais pacífica do mundo. Por outro lado, o Oriente Médio e o norte da África mantiveram a posição de regiões menos pacíficas.

Houve uma queda no índice global da paz, a média global desceu 0,27\% em relação ao ano de 2017. Entre os 163 países, 92 caíram em suas posições e 71 apresentaram melhorias. Como, também, em uma década, o relatório de 2018 apresentou o pior índice global de paz e no quesito de mortes em conflitos, no mundo todo, houve um aumento de $264 \%$.

A maior taxa de homicídios ficou com a América Central e Caribe, e, em segundo lugar, a América do Sul.

Ao considerarmos o relatório Global Peace Index, observamos que em alguns dos países mais pacíficos do mundo, como por exemplo, Suécia, Finlândia e Noruega, não foram encontradas notícias de casos de linchamentos a partir do ano 2000.

A seguir, partiremos para a apresentação da amostragem sobre a conduta de linchamento ao redor do mundo, objetivando um estudo comparado em relação às ocorrências brasileiras.

Os países serão apresentados por ordem alfabética. A relação foi construída conforme a identificação da reportagem na Internet. Salientamos que não se trata de um levantamento exaustivo, mas sim, exemplificativo. O objetivo, em regra, é exemplificar apenas um caso de linchamento do respectivo país. Houve, porém, exceções, já que em alguns países são tantas as ocorrências divulgadas pelas mídias jornalísticas, que optamos por citar mais de um exemplo e reproduzir alguns comentários publicados. 


\subsection{Amostragem - a partir do ano 2000}

\subsection{1. África ${ }^{4}$}

Muitos africanos consideram que o linchamento é a melhor solução contra a criminalidade, pois não confiam tanto nas autoridades de segurança, confiam mais na união da comunidade. Para o sociólogo moçambicano, Carlos Serra, do Centro de Estudos Africanos da Universidade Eduardo Mondlane, que há anos estuda os linchamentos, este fenômeno é a privatização da justiça (MADE FOR MINDS, 2016).

Em Bissau, capital guineense, um homem nigeriano foi linchado e faleceu por ser um suposto raptor de crianças. Na ocorrência, carros foram incendiados e a embaixada da Nigéria foi vandalizada por dezenas de pessoas. No Quênia é comum linchar. Em 2008, pelo menos 11 pessoas foram linchadas sob a acusação de bruxaria. No Uganda, as vítimas mortais da "justiça do linchamento" chegaram a 590, em 2014. Em 2013 homossexuais foram linchados, um deles foi queimado vivo. No Malawi, segundo a ONU, 16 pessoas foram assassinadas dessa forma. $\mathrm{Na}$ África do Sul, populares furiosos colocam um pneu cheio de gasolina numa pessoa e ateiam fogo. Em 2013, seis suspeitos de pertencer a uma gangue foram queimados vivos em Johanesburgo. Em Moçambique, em 2014, as autoridades registraram o linchamento de 24 pessoas. Em 2018, um homem morreu depois de ter sido vítima de um linchamento em Tete, no centro de Moçambique. A população do bairro de Degue decidiu fazer justiça com as próprias mãos, alegando que o homem era um ladrão. Segundo a Procuradoria-geral da República de Moçambique, o centro e o norte do país são as regiões mais problemáticas (MADE FOR MINDS, 2016; G1 GLOBO, 2018).

\subsubsection{Alemanha}

Em 2018, um homem de cinquenta anos, morador de Bremen no norte da Alemanha, foi vítima de uma tentativa de linchamento em sua casa e foi gravemente ferido. Os linchadores acreditaram que ele era um pedófilo exibido em uma reportagem na TV (DC, 2018).

\subsubsection{Argentina}

Conforme Luis Somoza, especialista em políticas de segurança, os linchamentos na Argentina ocorrem por causa do aumento da criminalidade em geral. Refletem a insegurança social, as pessoas sentem que estão desprotegidas, desamparadas, não há proteção do Estado. Por esse retrocesso ao estado primitivo da sociedade, é possível que surjam forças não estatais com o papel de defesa (de autodefesa, milícias, paramilitares ou esquadrões da morte) (FRAYSSINET, 2014).

O defensor penal juvenil da cidade de La Plata, Julián Axat, relata que há milhares de casos de surras nas detenções de adolescentes pobres, consideradas pelos policiais como corretivos, que são, na realidade, espécies de linchamentos e que não

\footnotetext{
4 Como o levantamento foi realizado por exemplificação apenas algumas regiões da África foram consideradas.
} 
são divulgados, já que não há punições por estas agressões. O defensor afirma que esta impunidade dos linchamentos gera a repetição da conduta (FRAYSSINET, 2014).

Em 2013, na província de Córdoba, ocorreram tentativas de linchamento contra jovens pobres e negros, provavelmente, os conhecidos linchamentos por racismo (FRAYSSINET, 2014).

Em 2014, em Rosário, Santa Fé, um jovem de 18 anos foi linchado e morreu por causa dos golpes que recebeu da multidão. Poucos dias depois, em outro caso, dois homens foram linchados por vizinhos depois de serem confundidos com ladrões. Em um período muito curto, ocorreram pelo menos nove casos de linchamentos em Santa Fé, Buenos Aires, Rio Negro, Córdoba e La Rioja (BBC, 2014).

\subsubsection{Bangladesh}

Em 2015, um garoto de 13 anos foi linchado até morrer. Seu linchamento foi gravado pelos próprios linchadores. Na gravação, o garoto foi amarrado em um poste por homens, que o espancaram usando um bastão de metal. A vítima gritava e chorava pedindo ajuda e água. O grupo celebrava e dizia que o vídeo seria publicado no Facebook. Após o garoto ter sido morto, o corpo foi levado a um aterro. O vídeo do linchamento e morte do garoto, de 13 anos, tornou-se viral nas redes sociais. Os homens o haviam acusado de tentar roubar um riquixá - uma bicicleta com uma carroça - na cidade de Sylhet (BBC, 2015).

\subsubsection{Bolívia}

Conforme a Defensoria do Povo, entre os anos 2005 e 2013, ocorreram 190 mortes por linchamentos, com isso, o país ocupa o segundo lugar no ranking mundial, perdendo apenas para a Guatemala (TERRA, 2014).

Em 2004, moradores da cidade boliviana de Ayo-Ayo lincharam o prefeito. Ele foi sequestrado em La Paz, ficou mais de doze horas em cativeiro e, após violento interrogatório e torturas, foi levado para a praça central da cidade, onde foi amarrado a um poste de eletricidade para que os espancamentos continuassem e, por fim, foi queimado ainda vivo. A multidão chegou a impedir a intervenção da polícia, chegando a agredir alguns jornalistas (VILAS, 2007).

Em 2012, uma multidão capturou e ateou fogo para queimar vivos dois brasileiros acusados de matar três bolivianos em San Matías, fronteira com Mato Grosso (G1 GLOBO, 2018).

Na região central de Cochabamba, um grupo de pessoas atacou três policiais acusados de corrupção, espancando-os até a morte. Na região de El Alto, houve um ataque violento, em que dois homens quase morreram, sendo colocados como bonecos com cordas amarradas no pescoço e pendurados em postes (BBC, 2008).

\subsubsection{China}

A partir de 2006, a prática de linchamentos virtuais virou moda entre os internautas chineses. Os chineses passaram a usar o meio de comunicação para encontrar alguém que odeiam, pedindo apoio para a sua condenação. A iniciativa beira a violência virtual (TERRA, 2007). 
Em 2009, onze chineses da etnia han foram acusados formalmente por envolvimento no linchamento de uigures, que deixou 200 mortos. O linchamento aconteceu por causa de um boato de que os uigures tinham abusado sexualmente de uma jovem (GLOBO, 2009).

Em 2017, dois homens foram linchados por roubarem em um vilarejo. Conforme vídeo disponibilizado na Internet, os homens foram arrastados pelos braços, agredidos e afogados (GOREBRASIL, 2017).

\subsubsection{Egito}

Em 2013, dois jovens foram linchados na cidade de Al-Gharbiyah. Eles foram espancados, supostamente, por roubar um riquixá e sequestrar duas crianças. Imagens divulgadas mostram os jovens pendurados pelos pés. O pai de um deles diz que foi incapaz de conter a fúria da multidão (BBC, 2013).

\subsubsection{Estados Unidos}

Em 2006, na Carolina do Sul, cinco adolescentes foram condenados por linchamento de um jovem negro. Vários estados americanos têm aprovado leis antilinchamento (G1 GLOBO, 2018).

Em 2012, Malcolm X Grassroots Movement (MXGM) publicou um relatório sobre os linchamentos de 110 negros (homens, mulheres e crianças afro-americanos), cometidos no primeiro semestre de 2012 por policiais, seguranças e agentes autônomos da "justiça”. Após a divulgação do relatório, ocorreram mais 10 mortes, ou seja, uma morte a cada 36 horas (HUFFPOST, 2012).

Em 2017, um estudante afro-americano foi esfaqueado e morto no campus da Universidade de Maryland, ato que foi chamado de linchamento (THRASHER, 2017).

Ainda em 2017, uma criança de oito anos foi empurrada por adolescentes de uma mesa de piquenique com uma corda no pescoço, ferindo-a. O menino foi levado ao hospital e, posteriormente, liberado. A avó do menino informou que ele e outros meninos estavam brincando em um quintal na vizinhança, quando adolescentes brancos começaram a agredi-lo verbalmente com expressões racistas, atirando-lhe pedras (NYTIMES, 2017).

Em 2018, NewSone publicou uma reportagem com o título: Fears Of Lynchings In Atlanta Area After Two People Are Found Hanging From Trees ${ }^{5}$. Isto após duas pessoas serem encontradas penduradas em árvores na área metropolitana de Atlanta: uma mulher foi encontrada morta perto de um Walmart em College Park, Geórgia, em 14 de maio, e um homem foi encontrado morto perto do Centro Universitário de Atlanta em 27 de abril (NEWSONE, 2018).

\subsubsection{França}

Em 2014, um imigrante romeno e cigano de 16 anos foi linchado por dezenas de pessoas. Os linchadores suspeitaram que o jovem cometia assaltos em Paris, em

5 Medos de linchamentos na região de Atlanta após duas pessoas serem encontradas penduradas em árvores. (Tradução livre). 
Seine-Saint Denis. Seu corpo, entre a vida e a morte, foi deixado em um carrinho de supermercado à beira da estrada nacional (PÚBLICO, 2014).

Em 2018, uma policial francesa foi linchada por uma multidão no subúrbio de Paris. O vídeo foi gravado pelos próprios agressores e disponibilizado na Internet (MAILONLINE, 2018).

Ainda em 2018, jovens, entre 16 e 17 anos, lincharam um homem, espancando-o com os pés, punhos e pedaços de madeiras. Testemunhas descreveram o linchamento como aterrorizante. Um homem foi esfaqueado fatalmente no coração, outro foi espancado até a morte. Dois incidentes separados envolvendo membros de gangues adolescentes (EXPRESS, 2018).

\subsubsection{Guatemala}

O maior número de registros de casos de linchamento é da Guatemala, sendo considerada pela ONU como a $5^{\text {a }}$ nação mais violenta do mundo (REGIONAL HUMAN DEVELOPMENT REPORT, 2013-2014).

A república de Guatemala, terceiro maior país da América Central, que possui como capital a cidade de Guatemala, é uma república democrática constitucional. A civilização Maia marca a história do país. A população é formada majoritariamente por indígenas e descendentes (REGIME JURÍDICO-INSTITUCIONAL DA GUATEMALA, 2018).

Conforme noticiado, a organização humanitária Grupo de Apoio Mútuo (GAM) apresentou um relatório que consta que, entre 2008 e 2015, registraram-se, na Guatemala, 1.367 casos de linchamentos, com 305 mortos e 1.062 pessoas feridas (SÁBADO, 2017).

Além disso, um relatório da Procuradoria de Direitos Humanos da Guatemala revelou que houve um significativo aumento na média de feridos e mortos em ações de linchamento (de 4,5 para 42,43 - no período de 2004 a 2013). Havendo um total de 295 assassinatos e 1.704 pessoas feridas. Além das ocorrências em que a comunidade retém os suspeitos de crimes, as chamadas retenções multitudinárias, que totalizaram 1.224 casos (ELPAÍS, 2014).

De acordo com o Programa das Nações Unidas para o Desenvolvimento (PNUD), a maioria dos linchamentos é motivada por sentimento de injustiça e são cometidos por multidões que buscam a suposta justiça popular (justiça de emergência). Há grupos que possuem o objetivo de livrar a sociedade ou comunidade de elementos indesejáveis (limpeza social), como viciados em drogas e prostitutas, havendo, nesses casos, acordo prévio para o linchamento. Há, também, as chamadas "execuções extrajudiciais", que contam com membros das forças de segurança do Estado. Por fim, há uma cultura doente de violência e desrespeito à lei na Guatemala que, conforme entrevista realizada com Cláudia Samayoa, pesquisadora, há um "clamor social para a aplicação de políticas repressivas e violentas" (EL PAÍS, 2014).

Portanto, são muitos os linchamentos que já ocorreram em Guatemala e continuam acontecendo. Alguns exemplos: 
- $\quad$ Em 2011, mais de 2.500 pessoas lincharam e mataram um jovem de 18 anos acusado de assalto, roubo, sequestro e estupro na capital da Guatemala (ELPAÍs, 2014).

- Em 2013, moradores de uma aldeia na região oeste da Guatemala lincharam uma mulher de 43 anos acusada de praticar bruxaria. Aproximadamente 2.000 vizinhos enfurecidos espancaram e jogaram pedras em Magdalena Francisco, após invadirem sua casa (NOTÍCIAS INTERNACIONAIS, 2013).

- Em 2015, o prefeito do vilarejo de Concepción, na Guatemala, foi linchado por uma multidão, que ainda ateou fogo em seu corpo. A multidão foi motivada pelo suposto fato do linchado ser o mandante de uma tentativa de assassinato de um rival, que resultou na morte de duas mulheres e em ferimentos em cinco pessoas (GLOBO, 2015).

- $\quad$ Em 2015, uma jovem foi espancada e queimada viva em praça pública. Pelos vídeos publicados o linchamento ocorreu com total selvageria (RT, 2015).

- Em 2017, um grupo de 300 pessoas tentou linchar evangélicos que faziam turismo na Guatemala por pensarem que eram delinquentes (SÁBADO, 2017).

\subsubsection{Haiti}

Segundo estatísticas da Polícia da ONU (UNPOL), a prática do linchamento é generalizada no Haiti e o número de casos conhecidos aumentou de 90 para 121 entre os anos 2009 e 2012. (ONUBR, 2013).

No Haiti, cidadãos comuns cometem o linchamento como punição de feitiçaria, roubo, suspeita de assassinato, entre outras infrações, apesar de a lei haitiana considerar o linchamento uma forma de assassinato, punível com prisão perpétua ou trabalhos forçados (ONUBR, 2013).

Em 2013, um homem que foi pego roubando uma cabra e uma galinha em Mirebalais, foi morto a pedrada pelos moradores locais.

\subsubsection{India}

Em 2015, na Índia, uma multidão com mais de 7.000 pessoas invadiu uma prisão e linchou um acusado de estupro.

No final de 2015 muitos muçulmanos foram assassinados em nome da luta pela proteção da vaca. Numa aldeia do norte do país, duzentas pessoas lincharam um homem de cinquenta anos e feriram gravemente seu filho. Em Caxemira, uma bomba caseira foi lançada contra um caminhão que transportava vacas, queimando e matando o motorista. No estado vizinho ao de caxemira um muçulmano de vinte anos, suspeito de tráfico de bovinos, foi espancado até a morte por vários indivíduos e outro acabou morto por uma turba de hindus que o acusavam de ter roubado uma vaca. (DIPLOMATIQUE, 2016).

Em 2018, no nordeste da Índia, a polícia prendeu 16 pessoas por terem linchado dois turistas que, supostamente, conforme circulava em redes sociais, eram sequestradores de crianças (TELEGRAPH, 2018). 
Em 2018, um homem foi linchado depois de uma pequena discussão sobre um acidente de moto. Uma foto foi tirada enquanto o seu corpo era levado ao hospital, porém, a vítima faleceu logo depois. A foto foi divulgada na Internet e havia a presença de policiais. A polícia do Estado, virtualmente, fez um pedido de desculpas (BBC, 2018).

\subsubsection{Inglaterra}

Em 2016, um homem polonês, condenado por estupro, foge da Inglaterra para não ser linchado pela população. Isso após a polícia tentar esconder sua identidade e não conseguir. $\mathrm{O}$ linchado de vinte anos foi considerado culpado de estupro em 2014, em seu país de origem, a Polônia, mas, circulava livremente pela Europa (EXPRESS, 2016).

\subsubsection{Itália}

No ano de 2015, em Nápoles, uma multidão enfurecida tentou linchar um dominicano de 23 anos acusado de molestar uma menina de 12 anos. A polícia conseguiu evitar o linchamento (IL MATINO, 2015).

Em 2017, um grupo de turistas napolitanos sofreu uma tentativa de linchamento. A ocorrência foi em Gallipoli, na província de Lecce. O grupo de turistas simulou que havia uma bomba no restaurante onde se encontrava, com o objetivo de não pagar a conta, o que provocou desespero nas pessoas que estavam no local. Quando, porém, essas pessoas souberam que era uma simulação, revoltaram-se contra o grupo de turistas. A polícia impediu o linchamento (PRP CHANEL, 2017).

\subsubsection{Líbia}

Em 2011, o ditador Muammar Kadhafi de 69 anos foi linchado até a morte após ser capturado. Ele tinha governado o país com mão de ferro durante 42 anos (G1 GLOBO, 2018).

\subsubsection{Madagáscar}

Em 2013, cidadãos franceses foram torturados e linchados por dezenas de pessoas e depois seus corpos foram queimados na pequena ilha de Nosy-Be, no norte do país (EURONEWS, 2013).

\subsubsection{México}

Conforme pesquisa realizada por Vilas (2007), no México, ocorreram 103 linchamentos entre 1987 e meados de 1998. Segundo outra pesquisa, posteriormente apresentada, ocorram 222 casos entre 1991 e 2003.

Em 2015, dois homens foram linchados por uma multidão de moradores. Eles foram queimados vivos na rua. As vítimas eram irmãos e funcionários de uma empresa de pesquisa do Distrito Federal e foram considerados sequestradores de crianças e idosos (ELPAÍS, 2015a). 
Em 2017, um cidadão russo, de 43 anos, foi internado no Hospital Geral de Cancún, com traumatismo craniano e lesões graves nos braços e nas costas, depois de uma tentativa de linchamento por um grupo de populares mexicanos em reação a comentários racistas nas redes sociais (OBSERVADOR, 2017).

Em 2018, usuários do metrô furiosos atacaram um suposto criminoso, porém, dois policiais impediram que a briga terminasse em linchamento, na estação Bosque de Aragón (SINEBARGO, 2018).

\subsubsection{Países do Oriente Médio}

No Irã, em 2006, uma iraniana foi linchada por ter mantido uma "relação ilegal” com dois homens, pois, no país, esse tipo de linchamento é lei (G1 GLOBO, 2018).

No ano de 2010, no Líbano, a cidade de Ketermaya ficou conhecida mundialmente como o palco do episódio onde um egípcio suspeito de homicídio foi linchado e pendurado em um poste (G1 GLOBO, 2018).

No ano de 2015, em Israel, um imigrante da Eritreia foi linchado por uma multidão após ser confundido com um terrorista. A vítima morreu, posteriormente, em um hospital (ELPAÍS, 2015).

No Afeganistão, em 2015, uma jovem foi linchada e queimada viva depois de ser acusada de queimar o Alcorão. Ela foi atropelada e arrastada por um carro. Posteriormente, foi divulgado que era inocente, ou seja, não tinha queimado o Alcorão. Imagens feitas por celular que circulam nas mídias sociais mostram que a polícia estava no local, mas, não salvou a vítima (GLOBO, 2015a).

\subsubsection{Paquistão}

Em 2017, um estudante de jornalismo de 23 anos, foi morto por uma multidão na Universidade Abdul Wali Khan, no norte da cidade de Mardan. Ele foi acusado de postar "conteúdo blasfemo" nas mídias sociais. Em 2018 um tribunal paquistanês condenou uma pessoa à morte e outras cinco à prisão perpétua pelo linchamento do estudante, que foi falsamente acusado de blasfêmia (RADIO MASHAAL, 2018).

\subsubsection{Peru}

Em 2004, uma multidão de aproximadamente três mil pessoas sequestrou o prefeito de Llave, o qual depois de várias horas e de ser brutalmente espancado pela multidão, veio a falecer. Seu corpo foi jogado na margem do rio Llave (VILAS, 2007).

Em 2018, a líder da etnia amazônica, Shipibo-Conibo, foi assassinada por um estrangeiro. Dois dias depois, um grupo de moradores linchou um cidadão canadense até a morte no mesmo povoado. Os moradores atribuíam a ele o assassinato da líder (ELPAÍS, 2018).

\footnotetext{
6 Como o levantamento foi realizado por exemplificação apenas algumas regiões do Oriente Médio foram consideradas.
} 


\subsubsection{Portugal}

Em 2007, um homem quase foi linchado em Campo Jales, na região de Vila Pouca de Aguiar (CM JORNAL, 2007).

Em 2010, um jovem de 18 anos foi linchado por cinco homens. A vítima faleceu no hospital de Braga (DIÁRIO DE NOTÍCIAS, 2010).

\subsubsection{República Dominicana}

Em 2018, duas pessoas, que mataram um comerciante local, foram linchadas por uma multidão. Conforme noticiado, os linchamentos na República Dominicana estão se tornando mais frequentes como forma de fazer justiça com as próprias mãos (PLENGLISH, 2018).

\subsubsection{Rússia}

Em 2018, um motorista de táxi de Moscou sofreu uma tentativa de linchamento por uma multidão de pessoas, que o perseguiram e o chutaram, mas, o homem conseguiu escapar. Isso ocorreu porque o motorista perdeu o controle do carro, após, por engano, ter pisado no acelerador em vez de pisar no freio, fazendo com que atropelasse alguns pedestres, ferindo-os.

\subsubsection{Venezuela}

Segundo especialistas, os linchamentos se multiplicam na Venezuela. De acordo com o Observatório Venezuelano de Conflito Social (OVCS), em 2015, houve 20 mortes por linchamento, em 2016, foram 126 mortes e no período de janeiro a maio, de 2017, foram 60 pessoas mortas e 36 linchados que conseguiram sobreviver. Um exemplo disso é que, em 2017, um homem de aproximadamente de 35 anos foi pego pelos transeuntes do local, por supostamente ter tentado roubar uma mulher. Em pouco tempo, estava nu e quase inconsciente na calçada, mas os chutes na cabeça e no rosto não paravam. As pessoas gritavam com ira e frustração: "Queimem-no!", "Maldito!" (AS VOZES DO MUNDO, 2017).

\subsection{Análise comparativa - Cenário brasileiro e internacional}

A amostragem apresentada comprova que o linchamento faz parte de muitas culturas e realidades sociais ao redor do mundo.

Michael Pfeifer $(2017 ; 2017 a)$ diz que o linchamento é, inicialmente, considerado americano, porém, a conduta ocorre em todo o mundo, tratando-se de um fenômeno transnacional, com raízes culturais, políticas e, na atualidade, a Internet passa a ser uma propulsora dessa espécie de violência. $\mathrm{O}$ pesquisador, em seus livros, faz levantamentos e análises sobre formas de violência coletiva e linchamento na África, Ásia, Oriente Médio, Europa e Américas.

Contemporaneamente, surgiu a terminologia de linchamento virtual. Conforme Macedo (2016), há semelhanças entre o ato de linchar fisicamente e o linchamento ocorrido em âmbito virtual. Uma dessas ocorre em muitos casos virtuais, ou 
seja, o desejo de se fazer justiça, tendo-se a aprovação popular, expondo e humilhando uma pessoa (vítima). A pesquisadora observa que o linchamento pode iniciar no âmbito virtual e prosseguir finalizando com a agressão física da pessoa exposta. Muitos casos de linchamentos físicos são motivados por narrativas que se iniciam nas redes sociais, a exemplo de muitas ocorrências na Ásia e na América do Sul. As agressões são filmadas e os vídeos são disponibilizados na Internet.

Ao analisarmos as ocorrências de linchamentos no Brasil e ao redor do mundo, constatamos notáveis semelhanças nas motivações. Muitos casos brasileiros e internacionais demonstram que os linchadores visam "fazer justiça com as próprias mãos", isto por sentirem que não existe justiça por parte da liderança governamental, havendo no final da execução uma sensação de "missão realizada", afinal, a justiça foi feita. Os crimes mais graves (cometidos supostamente pelos linchados), como homicídio, estupro ou lesões corporais, são crimes que motivam mais o linchamento.

Nos casos internacionais, podemos salientar as motivações por preconceito, racismo, crenças, misticismos ou culturas de extermínio, massacre por disputa de poder, influência ou conveniência (BARSTOW, 1995; MARTINS, 1996; SOUZA, 1999; OLIVEIRA, 2010; NATAL, 2012). Além dessas motivações, em relação à expressão "fazer justiça com as próprias mãos”, algumas figuras se destacam, por exemplo, a figura do justiceiro, como o denominado bandido social nobre (HOBSBAWM, 2010), aquele que tira dos ricos para dar aos pobres, por isso, a comunidade o admira e o apoia. A ocorrência, também, é denominada como autojustiça (autotutela) ou vigilantismo.

Nos casos dos brasileiros, analisando-se a motivação de se fazer a justiça com as próprias mãos, a insegurança da população com os órgãos governamentais e políticos se destacam. Manuel Eisner (2009), professor do Centro de Pesquisas em Criminologia da Universidade de Cambridge, esclarece que, no que diz respeito às regiões globais menos desenvolvidas, pelo fato de o Estado não fornecer suficiente proteção (principalmente quando o Estado e a polícia são reconhecidos como corruptos) surgem códigos culturais que visam uma espécie de proteção privada contra ameaças, o que desenvolve a violência como meio de resolução de conflitos.

Em 2016, foi publicada uma notícia no Jornal Inglês com o seguinte título: "Brazil grapples with lynch mob epidemic: A good criminal is a dead criminal". A reportagem constatou que, somente em 2016, 173 pessoas tinham sido mortas por multidões no Brasil (por média a cada dois dias a ocorrência de uma morte), sendo a cidade de Fortaleza, no Estado do Ceará, a primeira no ranking com, pelo menos, 14 casos. A matéria, ainda, salienta o levantamento feito pelo Fórum Brasileiro de Segurança Pública (FBSP), que concluiu que $57 \%$ da população brasileira concorda com a máxima "bandido bom é bandido morto". (THE GUARDIAN, 2016).

Apesar das possíveis semelhanças e diferenças de motivações, são notáveis as influências ambientais. $\mathrm{O}$ que nos faz constatar que os ambientes sociais, culturais, costumeiros, educacionais, familiares, religiosos, entre outros, influenciam demasiadamente em tais comportamentos humanos.

"Brasil lida com epidemia de linchamento: Um bom criminoso é um criminoso morto". (Livre tradução). 
Por fim, é salutar a observação de que, pela história da humanidade, a conduta de linchar outro da mesma espécie já existia desde as comunidades primitivas. Por exemplo, a história bíblica sobre Jesus. Ele foi linchado em sua época, por meio de torturas executadas com ritualismos em espetáculo público. Nesse sentido, podemos entender que a espécie humana traz em sua memória comportamental a ideia de que o mal deve ser combatido com o mal (bandido bom é bandido morto) e aquilo que é maligno deve ser eliminado de maneira que não subsista vestígios do mal aniquilado. De maneira ampliada, geral e histórica, compreendemos que a conduta de linchar o outro, na atualidade, é a repetitividade de barbáries que ocorreram durante toda a história da humanidade, isto com as peculiaridades da época, das motivações e influências ambientais.

\section{Considerações Finais}

Este artigo de investigação e reflexão crítica é resultado de pesquisa de doutoramento em Criminologia que ainda está em andamento. Analisamos a conduta de linchamento no Brasil e realizamos um estudo comparado por amostragem conveniente e não exaustiva, pesquisando sobre ocorrências de linchamento ao redor do mundo a partir do ano 2000.

O linchamento foi compreendido como a conduta de linchar outro(s) da mesma espécie em local público e com a participação de vários linchadores. Além disso, a conduta executória se desenvolve com ritualismo e manifestação intensa de emoções e sentimentos.

Observamos que o linchamento ocorre em muitos países e regiões do mundo. Não se tratando, portanto, de uma conduta que ocorre, apenas, em um ou dois países. Em países subdesenvolvidos ou em desenvolvimento, porém, há mais frequência de ocorrências. Os Estados Unidos representam uma exceção a essa observação, porém, observa-se que os linchamentos no País tendem a ser mais motivados por questões raciais. De maneira geral, as motivações apresentam variações, mas, nos casos exemplificados há predominância de se fazer justiça com as próprias mãos (o linchado era suspeito de crimes), de questões religiosas ou místicas e racismo.

Nos países subdesenvolvidos ou em desenvolvimento, podemos observar que a insatisfação da população é bem maior e pressupomos que isso se dá pela insegurança com o governo, policiamento, justiça, corrupção, bem como, pelas desigualdades sociais, falta de políticas de infraestrutura e habitacionais, carência educacional, carência familiar, etc., circunstâncias que poderiam aumentar o número de ocorrências de linchamento.

Dessa forma, concluímos nossos breves apontamentos sobre a conduta do linchamento ao redor do mundo, objetivando contribuir com pesquisas e análises no âmbito da ciência da Criminologia. 


\section{Referências}

ADORNO, S.; PASINATO, W. A Justiça não tempo, o ritmo da Justiça. Tempo soc. [online]. vol. 19, n. 2, p. 131-155, 2007. Disponível em: http://www.depen.pr.gov.br/ arquivos/File/ajusticanotempootempodajustica.pdf .

AS VOZES DO MUNDO. Linchamentos se multiplicam em meiò à crise na Venezuela. Por RFI., 2017. Disponível em: http://br.rfi.fr/americas/20170630-linchamentos-se-multiplicam-em-meio-crise-na-venezuela. Acesso em: 20 maio 2018.

BARSTOW, A. L. Chacina de feiticeiras: uma revisão histórica da caça às bruxas na Europa. Rio de Janeiro: José Olympio, 1995.

BBC. Bolívia questiona justiça comunitária após linchamentos. Por Andres Schipani. Disponível em: https://www.bbc.com/portuguese/reporterbbc/story/2008/04/080424_ linchamentos_bolivia_mv.shtml,2008. Acesso em: 25 maio de 2018.

BBC. Linchamento registrado em vídeo causa indignação no Egito. Disponível em: https://www.bbc.com/portuguese/noticias/2013/03/130320_egito_linchamento_video_rw, 2013. Acesso em: $1^{\circ}$ jun. 2018.

BBC. Onda de linchamentos preocupa governo na Argentina. Por Veronica Smink. Disponível em: https://www.bbc.com/portuguese/noticias/2014/04/140402_argentina_linchamentos_fn, 2014. Acesso em: $1^{\circ}$ jun. 2018.

$\mathrm{BBC}$. Vídeo viral de linchamento de garoto de 13 anos gera revolta em Bangladesh. Disponível em: https://www.bbc.com/portuguese/noticias/2015/07/150714_bangladesh_video_viral_hb, 2015. Acesso em: 2 jun. 2018.

BBC. India police 'sorry' for lynching photo. Disponível em: https://www.bbc.com/ news/world-asia-india-44572406, 2018. Acesso em: 2 jun. 2018.

BENEVIDES, M.V. Linchamentos no Brasil: violência e justiça popular. In: Roberto da Matta (Org.). Violência Brasileira. São Paulo: Brasiliense, v., p. 93-117, 1982.

CM JORNAL. Homem escapa a linchamento. Disponível em: http://www.cmjornal. pt/portugal/detalhe/homem-escapa-a linchamentohttp:/www.cmjornal.pt/portugal/ detalhe/homem-escapa-a-linchamento, 2017. Acesso em: 2 jun. 2018.

CÓDIGO PENAL BRASILEIRO. Decreto-lei n. 2.848, de 7 de dezembro de 1940. Diário Oficial da União, Rio de Janeiro, 1940.

DC. Tentativa de linchamento na Alemanha após exibição de reportagem sobre pedofilia na TV. Disponível em: http://dc.clicrbs.com.br/sc/noticias/noticia/2018/06/ tentativa-de-linchamento-na-alemanha-apos-exibicao-de-reportagem-sobre-pedofilia-na-tv-10375171.html, 2018. Acesso em: 2 jun. 2018. 
DIÁRIO DE NOTÍCIAS. Linchamento popular: cinco arguidos em liberdade. Por Paulo Julião. Disponível em: https://www.dn.pt/portugal/norte/interior/linchamento-popular-cinco-arguidos-em-liberdade-1557139.html, 2010. Acesso em: 4 jun. 2018.

DIPLOMATIQUE. Na Índia, linchamentos em nome da vaca sagrada. Por Naïke Desquesnes. Edição - 103. Disponível em: https://diplomatique.org.br/na-india-linchamentos-em-nome-da-vaca-sagrada, 2016. Acesso em: 2 jun. 2018.

D’AGOSTINO, R.; OLIVA, S.; SOUZA, P. E MILLER, G. Dias de Intolerância. Globo. com. Disponível em: http://g1.globo.com/politica/dias-de-intolerancia/platb/\#inicio, 2014. Acesso em 5 ago. 2018.

EISNER, M. The Uses of Violence: An Examination of Some Cross-Cutting Issues. International Journal of Conflict and Violence. IJCV : Vol. 3 (1), p. 40-59, 2009.

ELPAÍS. Os linchamentos e a impunidade se retroalimentam na América Central. Por José Meléndez. Disponível em: https://brasil.elpais.com/brasil/2014/04/16/internacional/1397664791_353323.html, 2014. Acesso em: 23 jun. 2018.

ELPAÍS. Israel investiga linchamento de imigrante confundido com terrorista. Disponível em: https://brasil.elpais.com/brasil/2015/10/19/internacional/1445253231_246733. html, 2015. Acesso em: 20 jun. 2018.

ELPAÍS. Dois homens são linchados e queimados no México. Por David Marcial Pérez. Disponível em: https://brasil.elpais.com/brasil/2015/10/20/internacional/1445376040_086264.html, 2015a. Acesso em: 20 jun. 2018.

ELPAÍS. Xamã assassinada e canadense linchado: uma história de terror no Peru. Por Jacqueline Fowks. Disponível em: https://brasil.elpais.com/brasil/2018/04/22/internacional/1524348805_920556.html, 2018. Acesso em: 20 jun. 2018.

EURONEWS. Madagáscar investiga linchamento de dois europeus em Nosy-Be. Disponível em: http://pt.euronews.com/2013/10/04/madagascar-investiga-linchamento-de-dois-europeus-em-nosy-be, 2013. Acesso em: 20 jun. 2018.

EXPRESS. Polish rapist 'flees Britain to avoid LYNCHING' after police tried to hide his identity. Disponível em: https://www.express.co.uk/news/uk/666833/Polish-migrantrapist-Shirebrook-lynching-Derbyshire-flee-UK, 2016. Acesso em: 22 jun.2018.

EXPRESS. Murder in the suburbs: Two men killed in wave of gang crime in France. By Romina Mcguiness.Disponível em: https://www.express.co.uk/news/world/963684/france-news-murder-paris-pau-seine-saint-denis-gang-crime, 2018. Acesso em: 22 jun 2018.

FOUCAULT, M. Microfísica do poder. 3 ed. Rio de Janeiro: Graal,1982.

FRAYSSINET, F. Os linchamentos e os “justiceiros” da Argentina. Disponível em: https://www.revistaforum.com.br/os-linchamentos-e-os-justiceiros-da-argentina, 2014. Acesso em: 22 jun. 2018. 
GLOBO. Onze são acusados de linchamento de uigures na China. Disponível em: http://g1.globo.com/Noticias/Mundo/0,,MUL1314831-5602,00-ONZE+SAO+ACUS ADOS+DE+LINCHAMENTO+DE+UIGURES+NA+CHINA.html, 2009. Acesso em: 22 jun. 2018.

GLOBO. Prefeito de vilarejo é linchado, queimado e morto na Guatemala. Disponível em: http:/g1.globo.com/mundo/noticia/2015/10/prefeito-de-vilarejo-e-linchado-queimado-e-morto-na-guatemala.html, 2015. Acesso em: 23 jun. 2018.

GLOBO. Afegã linchada por queimar o Alcorão era inocente, diz investigador. Disponível em: http://g1.globo.com/mundo/noticia/2015/03/afega-linchada-por-queimar-o-alcorao-era-inocente-diz-investigador.html, 2015a. Acesso em: 23 jun.2018.

GLOBO. Três anos depois, linchamento de Fabiane após boato na web pode ajudar a endurecer lei. Disponível em: https://g1.globo.com/e-ou-nao-e/noticia/tres-anos-depois-linchamento-de-fabiane-apos-boato-na-web-pode-ajudar-a-endurecer-lei. ghtml, 2017. Acesso em: 05 jun. 2018.

GOREBRASIL. Homens sendo brutalmente linchados por roubar na China. Disponível em: https://www.gorebrasil.com/homens-sendo-brutalmente-linchados-por-roubar-na-china, 2017. Acesso em: 20 jun. 2018.

G1 GLOBO. Dias de Intolerância. Disponível em: http://g1.globo.com/politica/dias-de-intolerancia/platb/\#mundo, 2018. Acesso em: 18 jun. 2018.

HOBSBAWM, E. Bandidos. São Paulo: Record, Paz e Terra, 2010.

HUFFPOST. A Lynching Happens Every 40 Hours. Disponível em: https://www.huffingtonpost.com/dr-david-j-leonard/lynching-happens-every-40-hours_b_1679948. html, 2012. Acesso em: 22 jun. 2018.

IEP. Global Peace Index. Disponível em: http://visionofhumanity.org/app/ uploads/2018/06/Global-Peace-Index-2018-2.pdf, 2018.

IL MATINO. Napoli. Quartieri spagnoli, dominicano rischia il linciaggio. La folla: "Ha stuprato una 12enne».Disponível em: https:/www.ilmattino.it/napoli/cronaca/ quartieri_spagnoli_dominicano-1121397.html, 2015. Acesso em: 16 jul. 2018.

JORNAL DE BRASÍLIA. Adolescente morre linchado em festa no Parque da Cidade. Disponível em: http://www.jornaldebrasilia.com.br/cidades/adolescente-morre-linchado-em-festa-no-parque-da-cidade, 2018. Acesso em: 31 maio 2018.

JORNAL ESTADO DE S.PAULO. Homem é linchado após tentativa de assalto a bar no Maranhão. Disponível em: https://brasil.estadao.com.br/noticias/geral,homem-e-linchado-apos-tentativa-de-assalto-a-bar-no-maranhao,1721191, 2015. Acesso em: 31 maio 2018. 
LEI DE TORTURA. Lei $n^{\circ}$ 9.455. Define os crimes de tortura e dá outras providências. Diário Oficial da União, Brasília, 1997.

MACEDO, K. T. M. Linchamentos Virtuais: Paradoxos Nas Relações Sociais Contemporâneas. Dissertação (Mestrado) - Faculdade de Ciências Aplicadas da Universidade Estadual de Campinas, Programa de Pós-graduação. Disponível em: http://repositorio.unicamp.br/bitstream/REPOSIP/321038/1/Mercuri KarenTank_M.pdf, 2016.

MACHADO, J. L. A. As Origens da Ku Klux Klan. Disponível em: http://srec.azores. gov.pt/dre/sd/115152010600/nova/dcsh/12/as_origens_da_ku_klux_klan.pdf, 2018. Acesso em: 5 jun. 2018.

MADE FOR MINDS. Linchamentos em África: porquê fazer justiça pelas próprias mãos? Por Theresa Krinninger / Bettina Riffel.Disponível em: http://www.dw.com/ pt-002/linchamentos-em-\%C3\%A1frica-porqu\%C3\%AA-fazer-justi\%C3\%A7a-pelas-pr\%C3\%B3prias-m\%C3\%A3os/a-19314028, 2016. Acesso em: 2 jun. 2018.

MAILONLINE. Horrific New Year's Day assault on a female police officer in Paris was filmed by her attackers as they kicked her around like a rag doll in 'cowardly and criminal lynching'. Disponível em:http://www.dailymail.co.uk/news/article-5226981/ New-Years-assault-policewoman-filmed-attackers.html, 2018. Acesso em: 7 jun. 2018.

MARTINS, J. de S. Linchamento, o lado sombrio da mente conservadora. Tempo Social; Rev. Sociol. USP, S.Paulo, 8(2): 11-26, outubro de 1996. Disponível em: http://www.scielo.br/pdf/ts/v8n2/0103-2070-ts-08-02-0011.pdf, 1996. Acesso em: 31 maio 2018.

MARTINS, J. de S. Quinhentos mil contra um -Linchamento é fruto de um Estado débil. No ranking do horror, São Paulo, Salvador e Rio lideram. Entrevista realizada por Flávia Tavares - O Estado de S.Paulo. Disponível em: http://sociologiaextreme.blogspot.com/2009/06/linchamento-o-texto-na-integra.html, 2009.

MARTINS, J. de S. Linchamento: A Justiça Popular no Brasil. São Paulo: Contexto, 2015.

MARTINS, J. de S. Linchamentos: violência e justiça popular no Brasil (Parte I). Entrevista por Mello, James. Conferências ILEA. Disponível em: http://hdl.handle. net/10183/130041, 2015. Acesso em 2 jun. 2018.

MARTINS, J. de S. Linchamentos: violência e justiça popular no Brasil (Parte II). Entrevista por Mello, James. Conferências ILEA. Disponível em: http://hdl.handle. net/10183/130043, 2015. Acesso em 2 jun. 2018.

MENANDRO, P. R. M., \& SOUZA, L. Linchamentos no Brasil: A justiça que não tarda, mas falha. Vitória: FCAA/UFES, 1991. 
NATAL, A. L. 30 anos de linchamento na Região Metropolitana de São Paulo 19802009. Dissertação (Mestrado em Sociologia) - Faculdade de Filosofia, Letras e Ciências Humanas, Universidade de São Paulo. São Paulo, p. 177. Disponível em: http://www. teses.usp.br/teses/disponiveis/8/8132/tde-18042013-121535/pt-br.php, 2012.

NEWSONE. Fears Of Lynchings In Atlanta Area After Two People Are Found Hanging From Trees.Disponível em: https://newsone.com/3798932/atlanta-area-lynchings-suicide, 2018. Acesso em: 2 jun. 2018.

NOTÍCIAS INTERNACIONAIS. Mulher acusada de bruxaria é linchada na Guatemala. Disponível em: https://noticias.r7.com/internacional/mulher-acusada-de-bruxaria-e-linchada-na-guatemala-07082013, 2013. Acesso em: 4 jun. 2018.

NYTIMES. New Hampshire Investigates Wounding of 8-Year-Old as Possible Hate Crime. Disponível em: https://www.nytimes.com/2017/09/13/us/biracial-boy-lynched-new-hampshire.html, 2017. Acesso em: 7 jun. 2018.

OBSERVADOR. Russo que sobreviveu a tentativa de linchamento no México vai ser deportado. Disponível em: https://observador.pt/2017/05/22/russo-que-sobreviveu-a-tentativa-de-linchamento-no-mexico-vai-ser-deportado, 2017. Acesso em: 20 jun. 2018.

OLIVEIRA, D. R. de. Quando “pessoas de bem” matam: um estudo sociológico sobre os linchamentos. Trabalho apresentado no 35 Encontro Anual da ANPOCS; GT34 Sociologia e antropologia da moral, 2010. Disponível em: https:/www.anpocs.com/ index.php/papers-35-encontro/gt-29/gt34-7/1218-quando-pessoas-de-bem-matam-um-estudo-sociologico-sobre-os-linchamentos/file, 2010. Acesso em: 4 jun. 2018.

ONUBR. ONU tenta acabar com prática de linchamento no Haiti. Disponível em: https://nacoesunidas.org/onu-tenta-acabar-com-pratica-de-linchamento-no-haiti, 2013. Acesso em: 2 jun. 2018.

PFEIFER, M. J. Global Lynching and Collective Violence: Volume 1: Asia, Africa, and the Middle East. Champaign: University of Illinois Press, 2017.

PFEIFER, M. J. Global Lynching and Collective Violence: Volume 2: The Americas and Europe. Champaign: University of Illinois Press, 2017a.

PLENGLISH. Lynching Increase in Dominican Republic. Disponível em: http://www. plenglish.com/index.php?o=rn\&id=25921\&SEO=lynching-increase-in-dominican-republic, 2018. Acesso em: 22 jun. 2018.

PRP Chanel. Gallipoli: gridano "ATTENTATO BOMBA" per non pagare il conto e rischiano il linciaggio. Disponível em: https://www.prpchannel.com/cronache/gallipoli-turisti-rischiano-linciaggio-falso-attentato, 2017. 
PÚBLICO. Indignação em França com linchamento de adolescente cigano. Por Clara Barata, Disponível em: https://www.publico.pt/2014/06/17/mundo/noticia/indignacao-em-franca-com-linchamento-de-adolescente-cigano-1659080, 2014. Acesso em: 22 jun. 2018.

RADIO MASHAAL. Pakistani Court Issues Death Sentence, Prison Terms For 'Blasphemy' Lynching. Disponível em: https:/www.rferl.org/a/pakistan-mashal-khan-court-death-sentence/29025260.html, 2018. Acesso em: 2 jun. 2018.

REGIME JURÍDICO-INSTITUCIONAL DA GUATEMALA. Disponível em: https:// www.oas.org/juridico/mla/pt/gtm/por_gtm-int-desc-system.pdf, 2018. Acesso em 22 jun. 2018.

REGIONAL HUMAN DEVELOPMENT REPORT. Citizen Security With A Human Face: Evidence and Proposals for Latin America. Disponível em: http://hdr.undp. org/sites/default/files/citizen_security_with_a_human_face_-executivesummary.pdf, 2013-2014.

RIOS, J. A. Linchamentos: Do Arcaico Ao Moderno. CDU 301.085.2. Ci. \& Trop., Recife 16(2): 207-236, jul\dez., 1988. Disponível em: https://periodicos.fundaj.gov.br/ CIC/article/view/425/31, 1988.

RT. Queriam vingança! Jovem é espancada e queimada viva por multidão no meio da rua. Disponível em: https://noticias.r7.com/hora-7/fotos/queriam-vinganca-jovem-e-espancada-e-queimada-viva-por-multidao-no-meio-da-rua-16062018\#!/ foto/1, 2015. Acesso em: 2 jun. 2018.

SÁBADO. Grupo de 20 evangélicos escapa a linchamento na Guatemala. Por Lusa. Disponível em: http://www.sabado.pt/mundo/america/detalhe/grupo-de-20-evangelicos-escapa-a-linchamento-na-guatemala, 2017. Acesso em: 23 jun. 2018.

SHERIF, M., Harvey, O., White, B., Hood, W., \& Sherif, C. Intergroup conflict and cooperation: the robbers case experimente. Norman, EUA: University of Oklaroma Book Exchange, 1961.

SINEBARGO. Usuarios del Metro intentan linchar a presunto ladrón en la estación Bosque de Aragón de la Línea B (VIDEO). Disponível em: http://www.sinembargo. $\mathrm{mx} / 17-05-2018 / 3419261,2018$. Acesso em: 8 jun.2018.

SINGER, H. Discursos Desconcertados: Linchamentos, Punições e Direitos Humanos. São Paulo: Humanitas, 2003.

SINHORETTO, J. Os justiçadores e sua justiça Linchamentos, costume e conflito. Dissertação (Mestrado em Sociologia) - Faculdade de Filosofia, Letras e Ciências Humanas, Universidade de São Paulo. São Paulo, p. 206. 2001. Disponível em: http:// www.nevusp.org/downloads/down175.pdf, 2001. 
Linchamentos: insegurança e revolta popular. Revista Brasileira de Segurança Pública | Ano $3^{\circ}$ Edição 4 Fev/Mar 2009. Disponível em: http://www.observatoriodeseguranca.org/files/artigo\%20jaqueline.pdf1, 2009.

SOUZA, L. de. Judiciário e exclusão: O linchamento como mecanismo de reafirmação de poder. Análise Psicológica (1999), 2 (XVII): 327-338. Disponível em: http:// repositorio.ispa.pt/bitstream/10400.12/5901/1/1999_2_327.pdf, 1999.

SZNICK, V. Tortura: histórico, evolução, crime. São Paulo: Leud, 1998.

TELEGRAPH. Two more lynched in India as police struggle to contain WhatsApp rumours of child kidnappers. Disponível em: https://www.telegraph.co.uk/ news/2018/06/11/two-lynched-india-police-struggle-contain-whatsapp-rumours-child, 2018. Acesso em: 2 jun. 2018.

TERRA. Linchamento virtual é moda polêmica na China. Disponível em: http://tecnologia.terra.com.br/noticias/0,,OI1640927-EI12884,00-Linchamento+virtual+e+moda+polemica+na+China.html, 2007. Acesso em: 2 jun. 2018.

Linchamentos: prática antiga assombra não só a Argentina. Por Jéssica Freitas. Disponível em: https://www.terra.com.br/noticias/mundo/linchamentos-pratica-antiga-assombra-nao-so-a-argentina,be44eab726e55410VgnVCM5000009ccceb0aRCRD.html, 2014. Acesso em: 2 jun. 2018.

THE GUARDIAN. Brazil grapples with lynch mob epidemic: 'A good criminal is a dead criminal'. Disponível em: https://www.theguardian.com/world/2016/dec/06/ brazil-lynch-mobs-vigilante-justice-fortaleza?CMP=share_btn_wa, 2016. Acesso em: 22 jun 2018.

THRASHER. S.W. The terror of lynching haunts black Americans again. Disponível em: https://www.theguardian.com/commentisfree/2017/may/24/lynching-threats-mississippi-racism-richard-collins, 2017. Acesso em: 22 jun. 2018.

VILAS, C. M. Linchamientos y conflito político en Los Andes. Versión revisada del documento presentado en el XXVI Congreso International de Lasa (San Juan, Puerto Rico), marzo de 2006. Folios, Segunda época, n. 25, Primer semestre de 2007, p. 3-26 Disponível em: http://www.scielo.org.co/pdf/folios/n25/n25a01.pdf, 2007. 
